\title{
Corporate Sustainability, Intangible Assets Accumulation and Competitive Advantage*
}

\author{
Francesco Perrini ${ }^{* *}$, Clodia Vurro ${ }^{* * *}$
}

\begin{abstract}
The article bridges corporate sustainability $(C S)$ and intangibles, deepening the mechanisms linking specific stakeholder-related CS policies and practices to intangible asset accumulation and competitive outcomes. The implementation of CS strategies, practices and processes strengthens company ability to identify, protect and give value to inimitable resources, stimulating the development of intangibles related to human capital, innovation and knowledge, culture and reputation.
\end{abstract}

Keywords: Corporate Sustainability; Intangible Assets; Competitive Advantage; Stakeholder Management

\section{Introduction}

With the rising complexity in global competitive dynamics, literature and managerial practice are converging on acknowledging intangible resources as the mainstays of business growth and value creation (Brondoni, 2000/2001; Lev, 2001; Zingales, 2000). Globalization, technological progress and the related fluctuations in market development rates have increasingly made entry barriers fragile, as well as the search for economies of scale hardly sustainable in the long run. In this changing context, foresighted firms have been those placing a bet on intangible asset accumulation.

In comparison with tangible assets, such as financial or physical resources, intangibles are less flexible (Chatterjee and Wernerfelt, 1991), hard to accumulate, and not easily transferred, given the fact that they are mostly idiosyncratic to firms

\footnotetext{
* The Authors: F. Perrini $\S \S 1,4 ;$ C. Vurro $\S \S 2,3$.

** Full Professor of Management, L. Bocconi University-Milan (francesco.perrini@ unibocconi.it)

*** Research Fellow of Management, L. Bocconi University-Milan (clodia.vurro@ unibocconi.it)

Edited by: ISTEI - University of Milan-Bicocca

ISSN: $1593-0319$

Perrini Francesco, Vurro Clodia, Corporate Sustainability, Intangible Assets Accumulation and Competitive Advantage Constraints, Symphonya. Emerging Issues in Management (symphonya.unimib.it), n. 2, 2010, pp. 25-38

http://dx.doi.org/10.4468/2010.2.03perrini.vurro
} 
and their members. For these reasons, intangible assets are barely imitable by competitors, thus having the potential to become the source of differential, longlasting performance for firms.

In light of the recognition of the differentiation advantages associated to the development of bundles of unique resources (Barney, 1991; Penrose, 1959), early academic debate on the categories of firm assets and their link to competitive gains has progressively shifted to the search for new sources of intangibles (Brondoni, 2009; Carmeli and Tishler, 2004).

Accordingly, building on the seminal contribution by Hart (1995) and related empirical validations (Sharma and Vredenburg, 1998), recent contributions have started to show how companies voluntarily responding to social and environmental concerns develop intangibles that can be sources of competitive advantage (Surroca et al., 2010).

Defined as a new managerial model based on the crucial value of stakeholder relationships and on the capacity of firms to strategically integrate social and environmental issues into business operations and interaction with stakeholders beyond legal requirements (Lambin, 2009; Perrini et al., 2006), corporate sustainability (CS) has gathered momentum as a timely competitive approach for increasing value (Porter and Kramer, 2006). According to theory, CS contributes to the bottom line via its favorable impact on the firm's relationships with important stakeholders (Freeman, 1984). Based on this assumption and enforced by empirical evidence, researchers have started to disentangle the impact of CS in specific management domains and stakeholder interactions (Aguilera et al., 2007), investigating how CS practices translate into organizational, managerial or market gains (Perrini et al., 2009).

Despite this growing interest in moving away from simplistic linear assumptions on the link between CS and financial and economic performance, only recently has research started to include intangibles as an outcome variable of CS strategies, based on the overall logic that CS increases the trustworthiness of a firm and so strengthens the relationships with critical stakeholders (Arrigo, 2009; Barnett, 2007).

Based on the recent advancements in the literature on the competitive case for $\mathrm{CS}$, our article aims at bridging CS and intangibles, deepening the mechanisms linking specific stakeholder-related CS policies and practices to intangible asset accumulation and competitive outcomes. To this end, the reminder of the article is structured as follows. First, recent literature on the performance consequences of CS integration is reviewed. Then, the links between CS investments and intangible assets are depicted. In line with the literature on intangibles the conceptual separation between stocks of capitals is maintained. Accordingly, intangibles are grouped into four well established categories: $(i)$ human capital, or the knowledge, skills and abilities residing with and utilized by individuals (Becker, 1993; Pfeffer, 1994); (ii) organizational capital, or the institutional knowledge (Teece, 1987), codified experience (Nelson and Winter, 1982), shared values, perceptions and feelings that differentiate firms from one another (Fiol, 1991); (iii) relational capital, or the quality and quantity of relationships in which a firm is embedded (Adler and Kwon, 2002); (iv) symbolic capital, or the firm's reputation and image such that its own values and visions are the ones considered acceptable and 
legitimate by stakeholder. Finally, a summary model is presented and conclusions drawn.

\section{The Competitive Case for Corporate Sustainability}

In the search for consistency between CS and firm's economic interests, the last thirty years have seen a large body of literature investigating the business case for $\mathrm{CS}$, that is, whether or not financial benefits to organizations engaged in actively contributing to social and environmental targets can meet or exceed the cost of such investments.

Over time the business case for CS has been approached in many different ways to prove or disprove the sound economic rationale for moving beyond shareholder value maximization. Though different in measures, approaches and results, the huge amount of quantitative analysis on this subject shares the same underlying definition of what CS should be: a strategic, profit-driven corporate response to changing pressures coming from the institutional, competitive and social context.

Since the first two studies published in 1972 (Bragdon and Marlin, 1972; Moskowitz, 1972), an increasing number of empirical investigations have been undertaken to address the economic and financial impacts of CS-related actions, tools and behaviors (for a review see De Bakker et al., 2005; Margolis and Walsh, 2003). Part of these studies support a negative impact of CS-related activities and behavior on performance, sharing a focus on the costs incurred through the engagement in social and environmental managerial practices. Critics of CS contend that expending limited resources on social and environmental issues decreases the competitive position of firms by unnecessarily increasing their costs (Barnett, 2007). Additionally these studies ward that taking into consideration stakes other than the exclusive interests of shareholders broadens managers' functions and discretion in such a way that, as a result, it waken managerial incentives, dilutes the structure of control, due to an agency loss, reduces financial performance (Friedman, 1970; Jensen, 2001).

However, the much richer number of studies supporting a positive relationship between social and economic performance seems to rule out misappropriation and misallocation concerns (Margolis and Walsh, 2003). In fact, a huge amount of studies reports a positive relationship between social and economic performance as the result of a stronger ability of firms to manage the expectations of their social context of reference (Waddock and Graves, 1997). As a whole such studies assume, often implicitly, that answering the expectations emerging from firms' stakeholder network lowers transaction costs, improves trust and legitimacy and sustains the ability of firms to face competition (Barnett, 2007).

Looking backward at the whole picture, there is no doubt that CS empirical accounts have improved over time, offering stronger theoretical rationales, more relevant operationalizations, and more and better controls for previously omitted variable. Yet, in an attempt to capture heterogeneity in firms' CS practices, as well as overcome inconsistencies in proving or disproving a universal rate of return to $\mathrm{CS}$, recent studies have started to emphasize the search for contingencies that could better represent the many facets that characterize CS and its related performance 
consequences (Aguilera et al., 2007). As a result, CS is less and less considered as a black box, rather as a complex set of stakeholder-specific dimensions variously impacting on the following areas: internal organization, consumer market, financial market, broad social communities of reference. A detailed analysis of stakeholderrelated studies is presented in the next section, highlighting the impact on intangibles as sources of competitive advantage.

\section{A Stakeholder View of Intangible Assets Accumulation}

With the aim to increase firm trustworthiness, to benefit from strengthened relationships with stakeholders, and to identify new sources of innovation and differentiation, managerial practice shows how companies actively engaged in integrating CS strategically into business operations are progressively broadening their range of activities, spanning from human resource management to community investing, from green innovation to sustainability in supply chains. In this context, though still fragmented, both theory and practice seem to move beyond a definition of CS as a black box, rather declining it into specific stakeholder-related activities and performance areas.

Adopting a stakeholder view of CS, we propose a model (Figure 1) that disentangles specific mechanisms through which CS may turn into intangible capital accumulation opportunities and competitive performance. Mechanisms and dynamics are detailed in the following sections.

Figure 1: CS, Intangibles and Competitive Performance

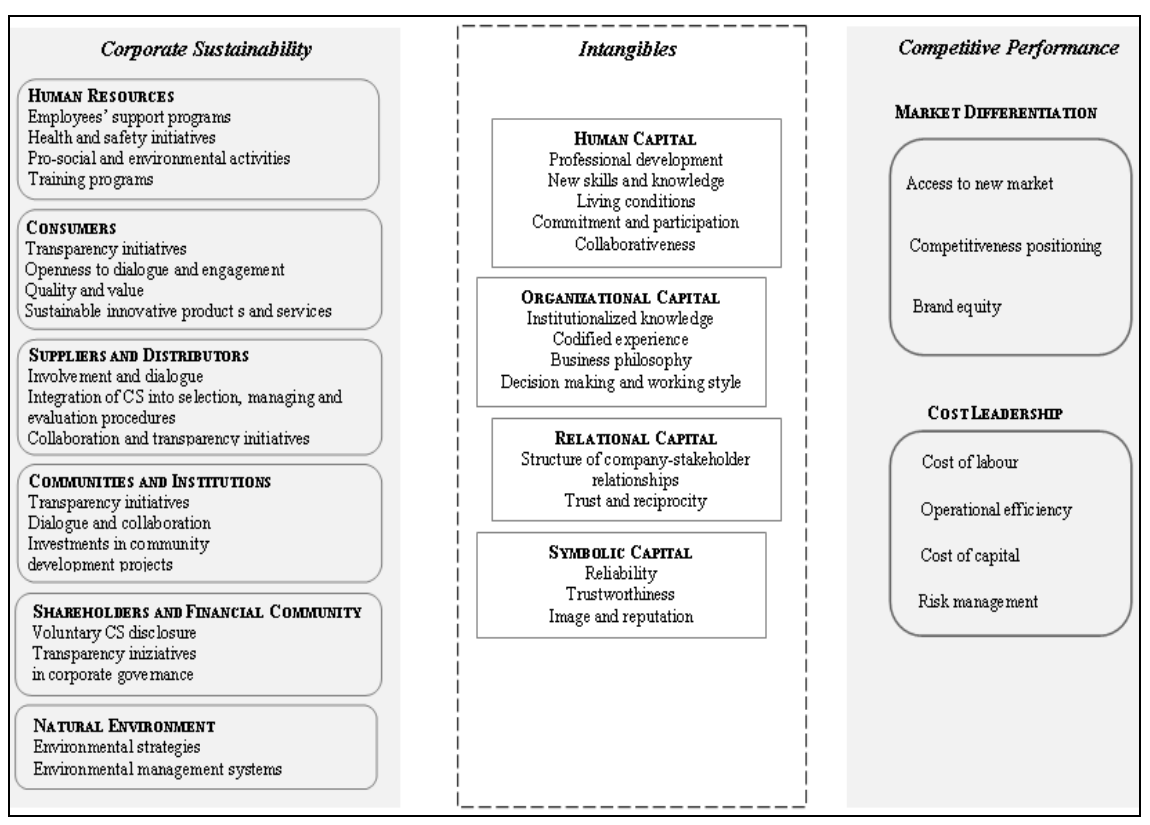

\subsection{CS and Internal Organization}

Giving value and relevance to organizational members and their well-being through investments in training, professional development, health and safety in the 
workplace and collaborative attitude, the integration of CS in human resource practices has a clear impact on human capital accumulation (Pfeffer, 1998). Stimulating participation, new knowledge creation (Hart and Milstein, 2003), and commitment, CS turns into operational and competitive benefits such as increased productivity, identification of growth and innovation opportunities, and efficiency gains through reduced costs due to health and safety risks, absenteeism or turnover. For example, employees' participation into pro-social activities (e.g., corporate volunteering programs) or employee support programs exert a positive impact on affective commitment to the organizations, turning into important behavioral outcomes ranging from decreased absenteeism and turnover to increased job performance (Grant et al., 2008).

$\square$ In 2002, Pfizer Corporation initiated the Global Health Fellows Programs, a program of international corporate volunteering aimed at developing the capacity of local health organizations in developing countries. Though framed as a strategic philanthropy initiative, GHF has primarily served as a professional development program, enhancing the personal and professional skills of participating employees through the challenge of working in multicultural and lowresource settings ${ }^{1}$.

At the same time, providing new frames to interpret organizational meanings and actions, CS has an impact on organizational capital accumulation, being an important source of fundamental changes in business philosophy, decision-making criteria, and ways of working together (Sharma and Vredenburg, 1998). Finally, CS addressing internal organization may have an impact on symbolic capital accumulation, aligning organizational member behavior with stakeholder expectations and enhancing corporate reputation as a reliable partner.

\subsection{CS and the Consumer Market}

With reference to the consumer market, companies have looked at CS as an opportunity to differentiate their offer and benefit from productivity gains while, at the same time, caring for social and environmental issues (Bhattacharya and Sen, 2004). In this renewed context, CS practices and related information disclosed to the consumer market have progressively become reliability indicators, strengthening company and brand positioning as a trustworthy partner in the market exchange (Jones and Murrel, 2001: 63).

Started in 2005, the Brand Imprint process represents a concrete attempt by Unilever to embed sustainability into innovation plans for their major brands. With the aim to make sustainability commitment more visible and relevant to customers, the process is based on continuous conversations with customers and their representatives from the early stages of brand development planning to product launch on consumer markets ${ }^{2}$. 
As a whole, literature on consumer responses to CS points out to its impact on symbolic capital accumulation (Greening and Turban, 2000). In this sense, firms that integrate CS in their relationships with customers have better chances to enhance their reputation as reliable, open, able to innovate and trustworthy exchange partners (Castaldo et al., 2009). Partly as a by-product of improved reliability, CS strengthens firm-consumer relationships affecting trust and reciprocity through increased transparency and openness to dialogue and cooperation (Frank, 2004). Finally, closeness to consumers and investment in new product and process development in social and environmental domains support companies in generating new knowledge and experience, thus affecting the stock of organizational capital available for innovation and growth (Hart, 1995).

\title{
3.3 CS and Supply Chain Management
}

The search for renewed approaches to supply chain management based on the discretionary allocation of corporate resources toward the improvement of crossboundary social and environmental performance finds its roots in the general loss of control over stages of production and distribution processes due to the progressive specialization of firms on single competence areas and the creation of global supply chains (Lim and Phillips, 2008; Schlegelmich and Öberseder, 2007).

Besides their impact on symbolic capital accumulation, due to a strengthened ability to manage reputational and legitimacy risks of being deemed responsible for suppliers' and distributors' practices, the diffusion of CS along the value chain has been proved to have relevant impacts on relational capital accumulation. In fact, with company activities spreading over a large number of countries and constituencies, the search for new coordination and control systems has lead both to the formulation and implementation of codes of conduct (van Tulder et al., 2009) and the development of collaborative practices aimed at strengthening trust, reciprocity, and reduce the potential for unbalanced use of power among firms in the supply chain (Drake and Schlachter, 2008).

\begin{abstract}
$\square$ Alessandro Bucci, buyer of the Green Coffee Department at Illycaffè states: 'Throughout the years Illycaffè has been capable of building a strong relationship with local growers based on trust. If I have to use a Brazilian Portuguese word to describe this situation, I would say 'parceria', which means a partnership between Illycaffè and our suppliers, in which both parties gain excellent results: we get the highest-quality Arabica coffee beans we are looking for, they receive knowledge, competences, support, and margins of course. ${ }^{3}$
\end{abstract}

Studies have started to show the benefits associated to long-term buyer-supplier relationships based on the ability to share knowledge and competences among partners (Vurro et al., 2009), raising opportunities for organizational capital accumulation (Frank, 2004), due to easier knowledge exchange, improved coordination, higher innovation potential, higher value delivered to final markets. 


\subsection{CS and the Social Context}

Over time, firms have converged on acknowledging the competitive potential related to discretionary investments in community development projects or relationships with public and nonprofit organizations (Porter and Kramer, 2002), especially in term of relational and symbolic capital accumulation.

The development of a collaborative approach with community has been showed to have a prominent impact on leveraging company image and reputation, conveying that license or freedom to operate, which can support company operations and survival in the long haul (Googins and Rochlin, 2000; Warner and Sullivan, 2004).

Moreover, partnerships and community engagement have the potential to support firms in the development of a proactive attitude toward their context of reference, helping them to foresee dynamics of change and potentially risky challenges (Kanter, 1999).

Launched in 2007, M-Pesa, which stands for Mteja-Pesa or 'Mobile Money' in Swahili, is a mobile banking service offered by Vodafone and operated by Safaricom, a Vodafone's subsidiary in Kenya and the country's largest mobile network operator. The project would not have been feasible without the commitment of a large network of local banks and financial institutions, nonprofits, local governments and community organizations. M-Pesa is more than an outstanding case of a multinational corporation cooperating across sector boundaries to introduce a new service. Vodafone decision to enter into such a complex, multi-sector alliance is not only an attempt to gain access to complementary resources, but also to establish itself as a worth partners in a growing, attractive market. ${ }^{4}$

More recently, the direct impact of firm-community collaborations in social projects on innovation have been investigated (Holmes and Moir, 2007). Nonprofits' technical expertise and knowledge about the served communities, have the potential to accelerate innovation by reassuring business partners about the existence of unmet needs. With specific regard to the initiative to alleviate poverty and redistribute wealth at the Bottom-of-the-Pyramid, nonprofits are much closer to the end users than companies. Nonprofits can also support business partners in testing new technologies (Kanter, 1999).

Finally, the implementation of community dialogue procedures, interaction and collaboration represent opportunities for relational capital accumulation (Maak and Pless, 2006), lowering transaction costs and generating a durable competitive advantage through trust- and legitimacy-based linkages.

\subsection{CS and the Financial Community}

Research has devoted considerable attention to the beneficial impacts of implementing CS practices and processes aimed at improving relationships with shareholder and the financial community at large. Most of the existing studies have 
centered on the role of disclosing voluntary information on social and environmental performance beyond legal requirements (Perrini, 2006; Salvioni, 2002).

According to the most recent contributions, disclosure through ad hoc reports acts as a signaling exercise to explicitly define the company to interested stakeholders, thus avoiding potential adverse selection risks and the exposure to future social costs (Dye, 1985).

At the same time, within a social context of changing reciprocal expectations, voluntary CS disclosure supports firms in facing social and political pressures to act in socially acceptable ways, thus shaping stakeholder perceptions and expectations about actual changes in corporate behavior and turning into a stronger corporate ability to manage potential legitimacy threats (Abbott and Monsen, 1979). Since stakeholders are likely to favor the company they view as legitimate, appropriate disclosure and reporting support relational and symbolic capital accumulation through making stakeholders aware that corporate procedures are fair (Orlitzky and Benjamin, 2001).

Finally, beyond cost-benefit analysis and the search for legitimacy and reputation, the practice of CS disclosure and reporting mirror certain adaptive managerial styles of dealing with an increasingly dynamic environment (Salvioni and Bosetti, 2006). Accordingly, disclosure has a direct impact on organizational capital accumulation, improving managerial awareness of and control over the social and environmental impact of corporate activities, a vehicle toward an improved ability to manage dialogue with stakeholders over time (Bowman and Haire, 1975).

\subsection{CS and Environmental Management}

Competitive gains associated to the development of an organization-wide sensitivity to the natural environment through the implementation of new managerial approaches are well established in the literature.

First of all, the adoption of environmental technologies aimed at monitoring and reducing corporate environmental impacts is likely to become a source of product innovation (e.g., green products), allowing firms to improve product differentiation and competitive positioning (Shrivastava, 1995). At the same time, environmental policy may generate process innovations. Research has highlighted how pollution abatement strategies requires the redesign of a entire stages of production processes to increase material savings and reduce energy consumption, thus turning into efficiency and effectiveness gains in the use of resources (King and Lenox, 2001).

$\square 3 M$ is a well-known case of innovating firm in pollution prevention, developing the first successful industrial program committed to source reduction through product reformulation, process modification, equipment redesign, recycling and reuse. The program $3 M$ created was called 3P, or Pollution Prevention Pays. The 3M example was followed by other companies who successfully proved the advantages of green management. For example, in 1979 Novartis made only 30 units of finished products for every 70 units of waste, but by 2000, because of 
extensive efforts to prevent pollution, it produced 75 units of finished products for every 25 units of waste. ${ }^{5}$

Moreover, empirical research has shown that reducing pollution, improving waste management and implementing procedures to minimize environmental impacts act as a reputation signaling exercise, allowing firms to accumulate symbolic capital. This becomes crucial as it opens new markets, especially in spite of the growing interest in green public and private purchasing (Ambec and Lanoie, 2008).

As for social initiatives and tools, corporate commitment to strengthen environmental performance has been shown to be linked to better, long-lasting relationships with stakeholders due to lower perceived risks and stronger legitimacy. In this context, less pollution induces lower liability costs, avoiding potentially costly litigation and fines (Schaltegger and Wagner, 2006), allowing firms to have easier access to capital and win on the financial market.

Finally, the adoption of proactive environmental strategies leads to the designing of high-commitment human resource practices, such as, for example, environmental training initiatives, compensation packages to reward employee contribution to environmental impact reduction, which encourage employee involvement in environmental improvements (Hart, 1995; Surroca et al., 2010), thus contributing to human capital accumulation.

\section{Emerging Issues}

Companies are increasingly searching for strategies to be different in a valuable way compared to their actual and potential competitors. In this context, CS represents a valuable source of competitiveness for companies strategically investing in it, through the integration of social and environmental sensitivity in corporate operations and interaction with stakeholders.

Combining economic prosperity, social cohesion and environmental protection, CS supports firms in the process of intangible assets' accumulation, strengthening company ability to identify, protect and give value to inimitable resources, such as skills and competences, knowledge and values, legitimacy, trust and reputation in the stakeholder network.

This study was meant to clearly picture the complex portrait of causal relationships between specific investments in CS, intangible accumulation and competitive advantages based either on cost leadership or market differentiation. According to the model proposed, the implementation of CS strategies, practices and processes aimed at answering to stakeholder needs and requests stimulates the development of intangibles related to human capital, innovation and knowledge, culture and reputation, while ameliorating the quantity and quality of relationships between firms and their stakeholders.

Proposing a taxonomy of the causal relationships between CS, intangibles and competitive performance, our study opens up new perspectives on both the dispersion of results in the studies on the performance consequences of CS and on the search for new processes of intangible creation and development. On the one side, pointing out to the relevance of setting clear boundaries and specifying levels 
of analysis in order to generate comparable results, our study gives way to further research on the many facets of CS and how they affect specific performance areas in the relationship with different categories of stakeholders. On the other side, we contribute to an explanation about the way in which intangibles can be accumulated, suggesting to scholars new venues to investigate intangibles and to managers where to place investments in order to benefit from CS and generate new sources of competitive advantage. This search becomes increasingly urgent as competitive dynamics accelerate, with firms' survival put at stake in the long run.

\section{Bibliography}

Abbott Walter F., Monsen R. Joseph, On the Measurement of Corporate Social Responsibility: Self Reported Disclosures as a Methods of Measuring Corporate Social Involvement, Academy of Management Journal, vol. 22, n. 3, 1979, pp. 501-515. http://dx.doi.org/10.2307/255740

Adler Paul S., Kwon Seok-Woo, Social Capital: Prospects for a New Concept, Academy of Management Review, vol. 27, n. 1, 2002, pp. 17-40. http://dx.doi.org/10.2307/4134367

Aguilera Ruth V., Rupp Deborah E., Williams Cyntia A., Ganapathi Jyoti, Putting the S Back to Corporate Social Responsibility: a Multilevel Theory of Social Change in Organizations, Academy of Management Review, vol. 32, n. 3, 2007, pp. 836-863. http://dx.doi.org/10.5465/AMR.2007.25275678

Ambec Stefan, Lanoie Paul, Does It Pay to Be Green? A Systematic Overview, Academy of Management Perspective, vol. 22, n. 4, 2008, pp. 45-62.

http://dx.doi.org/10.5465/AMP.2008.35590353

Arrigo Elisa, Market-Driven Management, Global Competition and Corporate Responsibility, Symphonya. Emerging Issues in Management (symphonya.unimib.it), n. 1, 2009. http://dx.doi.org/10.4468/2009.1.06arrigo

Barnett Michael L., Stakeholder Influence Capacity and the Variability of Financial Returns to Corporate Social Responsibility, Academy of Management Review, vol. 32, n. 3, 2007, pp. 794816. http://dx.doi.org/10.5465/AMR.2007.25275520

Barney Jay, Firm Resources and Sustained Competitive Advantage, Journal of Management, vol. 17, n. 1, 1991, pp. 99-120. http://dx.doi.org/10.1177/014920639101700108

Becker Gary S., Human Capital: A Theoretical and Empirical Analysis, The University of Chicago Press, Chicago, 1993.

Bhattacharya C.B., Sen Sankar, When, Why, and How Consumers Respond to Social Initiatives, California Management Review, vol. 47, n. 1, 2004, pp. 9-24. http://dx.doi.org/10.2307/3850493

Bowman Edward H., Haire Mason, A Strategic Posture Toward Corporate Social Responsibility, California Management Review, vol. 18, n. 2, 1975, pp. 49-58.

Bragdon J.H., Marlin J.A.T., Is Pollution Profitable?, Risk management, vol. 19, n. 4, 1972, pp. 918.

Brondoni Silvio M., Brand Policy and Brand Equity, Symphonya. Emerging Issues in Management (symphonya.unimib.it), n. 1, 2000/2001. http://dx.doi.org/10.4468/2001.1.02brondoni 
Brondoni Silvio M., Market-Driven Management, Competitive Customer Value and Global Network, Symphonya. Emerging Issues in Management (symphonya.unimib.it), n. 1, 2009. http://dx.doi.org/10.4468/2009.1.02brondoni

Carmeli Abraham, Tishler Ashler, The Relationships between Intangible Organizational Elements and Organizational Performance, Strategic Management Journal, vol. 25, n. 13, 2004, pp. 1257 1278.

http://dx.doi.org/10.1002/smj.428

Castaldo Sandro, Perrini Francesco, Misani Nicola, Tencati Antonio, The Missing Link Between Corporate Social Responsibility and Consumer Trust: the Case of Fair Trade Products, Journal of Business Ethics, vol. 84, n. 1, 2009, pp. 1-15. http://dx.doi.org/10.1007/s10551-008-9669-4

Chatterjee Savan, Wernerfelt Birger, The Link Between Resources and Type of Diversification: Theory and Evidence, Strategic Management Journal, vol. 12, n. 1, 1991, pp. 761-771. http://dx.doi.org/10.1002/smj.4250120104

De Bakker Frank G. A., Groenewegen Peter, Den Hond Frank, A Bibliometric Analysis of 30 Years of Research and Theory on Corporate Social Responsibility and Corporate Social Performance, Business \& Society, vol. 44, n. 3, 2005, pp. 283-317. http://dx.doi.org/10.1177/0007650305278086

Drake Mattehw J., Schlachter John Teepen, A Virtue-Ethics Analysis of Supply Chain Collaboration, Journal of Business Ethics, vol. 82, n. 4, 2008, pp. 851-864. http://dx.doi.org/10.1007/s10551-007-9597-8

Dye Ronald A., Disclosure of Nonproprietary Information, Journal of Accounting Research, vol. 23, n. 1, 1985, pp. 123-145. http://dx.doi.org/10.2307/2490910

Fiol C. Marlene, Managing Culture as a Competitive Resource: an Identity-Based View of Sustainable Competitive Advantage, Journal of Management, vol. 17, n. 1, 1991, pp.1224-1260. http://dx.doi.org/10.1177/014920639101700112

Frank R.H., What Price the Moral High Ground? Ethical Dilemmas in Competitive Environments, Princeton University Press, Princeton, 2004.

Freeman R. Edward, Strategic Management: a Stakeholder Approach, Pitman, Boston, 1984.

Friedman Milton, The Social Responsibility of Business Is to Increase Its Profits, New York Times Magazine, 13 September, 1970, pp. 122-126.

http://dx.doi.org/10.1007/978-3-540-70818-6_14

Googins Bradley K., Rochlin Steven A., Creating The Partnership Society: Understanding the Rhetoric and Reality of Cross-Sectoral Partnerships, Business \& Society Review, n. 105, 2000, pp. 127-144. http://dx.doi.org/10.1111/0045-3609.00068

Grant Adam M., Dutton Jane E., Rosso Brent D., Giving Commitment: Employee Support Programs and the Prosocial Sensemaking Process, Academy of Management Journal, vol. 51, n. 5, 2008, pp. 898-918. http://dx.doi.org/10.5465/AMJ.2008.34789652

Greening Daniel W., Turban Daniel B., Corporate Social Performance as a Competitive Advantage In Attracting a Quality Workforce, Business \& Society, vol. 39, n. 3, 2000, pp. 254-280. http://dx.doi.org/10.1177/000765030003900302

Hart Stuart L., A Natural Resource-Based View of the Firm, Academy of Management Review, vol. 20, n. 4, 1995, pp. 986-1014. http://dx.doi.org/10.5465/AMR.1995.9512280033

Hart Stuart L., Milstein Mark B., Creating Sustainable Value, Academy of Management Executive, vol. 17, n. 2, 2003, pp. 56-69.

http://dx.doi.org/10.5465/AME.2003.10025194 
Holmes Sara, Moir Lance, Developing a Conceptual Framework to Identify Corporate Innovations through Engagement with Non-Profit Stakeholders, Corporate Governance: The International Journal of Business in Society, vol. 7, n. 4, 2007, pp. 414-422. http://dx.doi.org/10.1108/14720700710820498

Jensen M.C., Value Maximization, Stakeholder Theory, and the Corporate Objective Function, Journal of Corporate Applied Finance, vol. 14, n. 3, 2001, pp. 8-21. http://dx.doi.org/10.1111/j.1745-6622.2001.tb00434.x

Jones Ray, Murrel Audrey, Signaling Positive Corporate Social Performance. An Event Study of Family-Friendly Firms, Business \& Society, vol. 40, n. 1, 2001, pp. 59-78. http://dx.doi.org/10.1177/000765030104000105

Kanter Rosabeth Moss, From Spare Change to Real Change: the Social Sector as Beta Site for Business Innovation, Harvard Business Review, vol. 77, n. 3, 1999, pp. 122-132.

King Andrew A., Lenox Michael J., Does It Really Pay to Be Green? Accounting for Strategy Selection in the Relationship between Environmental and Financial Performance, Journal of Industrial Ecology, vol. 5, n. 1, 2001, pp. 105-116. http://dx.doi.org/10.1162/108819801753358526

Lambin Jean-Jacques, Capitalism and Sustainable Development, Symphonya. Emerging Issues in Management (symphonya.unimib.it), n. 2, 2009. http://dx.doi.org/10.4468/2009.2.02lambin

Lev Baruch, Intangibles: Management, Measurement and Reporting, The Brookings Institute Press, Washington, 2001.

Lim Suk Jun, Phillips Joe, Embedding CSRvalues: The Global Footwear Industry's Evolving Governance Structure, Journal of Business Ethics, vol. 81, n. 1, 2008, pp. 143-156. http://dx.doi.org/10.1007/s10551-007-9485-2

Maak Thomas, Pless Nicola M., Responsible Leadership in a Stakeholder Society. A Relational Perspective, Journal Of Business Ethics, vol. 66, n. 1, 2006, pp. 99-115. http://dx.doi.org/10.1007/s10551-006-9047-z

Margolis Joshua D., Walsh James P., Misery Loves Companies: Rethinking Social Initiatives by Business, Administrative Science Quarterly, vol. 48, n. 2, 2003, pp. 268-305. http://dx.doi.org/10.2307/3556659

Moskowitz Milton, Choosing Socially Responsible Stocks, Business \& Society Review, vol. 72, n. 1, 1972, pp. 71-75.

Nelson Richard R., Winter Sidney G., An Evolutionary Theory of Economic Change, Harvard Business School Press, Cambridge, 1982

Orlitzky M. , Benjamin J.D., Corporate Social Performance and Firm Risk: a Meta-Analytic Review, Business \& Society, vol. 40, n. 4, 2001, pp. 369-396. http://dx.doi.org/10.1177/000765030104000402

Penrose Edith T., The Theory of the Growth of the Firm, Oxford University Press, New York, 1959.

Perrini Francesco, The Practitioner's Perspective on Non-Financial Reporting, California Management Review, vol. 48, n. 2, 2006, pp. 73-103.

Perrini Francesco, Pogutz Stefano, Tencati Antonio, Developing Corporate Social Responsibility. A European Perspective, Edward Elgar Publishing, Cheltenham, 2006.

Perrini Francesco, Russo Angeloantonio, Tencati Antonio, Vurro Clodia, Going Beyond a LongLasting Debate: What Is Behing the Relationship between Corporate Social and Financial Performance?, European Academy for Business in Society (ed.), Corporate Responsibility, Market Valuation and Measuring the Financial and Non-Financial Performance of the Firm, Cranfield School Of Management, SDA Bocconi, Vlerick Leuven Gent Business Schools, 2009. 
Pfeffer Jeffrey, Competitive Advantage through People, California Management Review, vol. 36, n. 2, 1994, pp. 9-28. http://dx.doi.org/10.1002/job.4030150608

Pfeffer Jeffrey, The Human Equation: Building Profits by Putting People First, Harvard Business School Press, Boston, 1998.

Porter M., Kramer M., Strategy and Society: the Link Between Competitive Advantage and Corporate Social Responsibility, Harvard Business Review, vol. 84, n. 12, 2006, pp. 78-92.

Porter Michael E., Kramer Mark R., The Competitive Advantage of Corporate Philanthropy, Harvard Business Review, vol. 80, n. 12, 2002, pp. 57-68.

Salvioni Daniela M., Transparency Culture and Financial Communication, Symphonya. Emerging Issues in Management (symphonya.unimib.it), n. 2, 2002. http://dx.doi.org/10.4468/2002.2.04salvioni

Salvioni Daniela M., Bosetti Luisa, Corporate Governance Report and Stakeholder View, Symphonya. Emerging Issues in Management (symphonya.unimib.it), n. 1, 2006. http://dx.doi.org/10.4468/2006.1.03salvioni.bosetti

Schaltegger Stefan, Wagner Marcus (eds.), Managing the Business Case for Sustainability, Greenleaf Publishing, Sheffield, 2006.

Schlegelmich Bodo B., Öberseder Magdalena, Ethical Issues in Global Supply Chains, Symphonya. Emerging Issues in Management (symphonya.unimib.it), n. 2, 2007. http://dx.doi.org/10.4468/2007.2.03schlegelmich.oberseder

Sharma Sanjay, Vredenburg Harrie, Proactive Corporate Environmental Strategy and the Development of Competitively Valuable Organizational Capabilities, Strategic Management Journal, vol. 19, n. 8, 1998, pp. 729-753. http://dx.doi.org/10.1002/(SICI)1097-0266(199808)19:8<729::AID-SMJ967>3.0.CO;2-4

Shrivastava P., Environmental technologies and competitive advantage, Strategic Management Journal, 16, 1995, pp. 183-200. http://dx.doi.org/10.1002/smj.4250160923

Surroca Jordi, Tribò Jorep A., Waddock Sandra, Corporate Responsibility and Financial Performance: the Role of Intangible Resources, Strategic Management Journal, vol. 31, n. 5, 2010, pp. 463-490. http://dx.doi.org/10.1002/smj.820

Teece David J. (ed.), The Competitive Challenge: Strategies for Industrial Innovation and Renewal, Ballinger Publishing Co., Cambridge, 1987.

van Tulder Rob, van Wijk Jeroen, Kolk Ans, From Chain Liability to Chain Responsibility, Journal of Business Ethics, 85, Supplement 2, 2009, pp. 399-412. http://dx.doi.org/10.1007/s10551-008-9742-z

Vurro Clodia, Russo Angeloantonio, Perrini Francesco, Shaping Sustainable Value Chains: Network Determinants of Supply Chain Governance Models, Journal of Business Ethics, 90, Supplement 4, 2009, pp. 607-621. http://dx.doi.org/10.1007/s10551-010-0595-x

Waddock Sandra, Graves Samuel B., The Corporate Social Performance - Financial Performance Link, Strategic Management Journal, vol. 18, n. 4, 1997, pp. 303-319. http://dx.doi.org/10.1002/(SICI)1097-0266(199704)18:4<303::AID-SMJ869>3.0.CO;2-G

Warner Michael, Sullivan Rory, Putting partnerships to work: Strategic alliances for development between the government, the private sector and civil society, Greenleaf Publishing Limited, Sheffield, UK, 2004.

Zingales Luigi, In Search of New Foundations, Journal of Finance, vol. 55, n. 4, 2000, pp. 1623 1653. 


\section{Notes}

${ }^{1}$ See Vian T. et al. 2007, Corporate Social Responsibility in Global Health: The Pfizer Global Health Fellows International Volunteering Program, Human Resource Planning, 30/1, pp. 30.35.

${ }^{2}$ See Unilever, Sustainable Development Report 2009

${ }^{3}$ See Perrini F. and Russo A. 2008, Illycaffè: Value Creation through Responsible Supplier Relationships, Journal of Business Ethics Education, 5(Special Issue), pp. 83-114.

${ }^{4}$ See Vurro, C. et al. 2010, Institutional Antecedents of Partnering for Social Change: How Institutional Logics Shape Cross-Sector Social Partnerships, Journal of Business Ethics, Forthcoming.

5 See Marcus, A. and Fremeth A. 2009, Green Management Matters Regardless, Academy of Management Perspectives, 23/3, p. 20. 